\title{
REDESAIN INTERIOR MOBIL TOILET KELILING UNTUK DIFABEL DI KAWASAN MONAS, JAKARTA PUSAT
}

\author{
Irma Damayantie, Nabila Delaseptina* \\ Program Studi Desain Interior \& Program Studi Desain Komunikasi \\ Visual, Fakultas Desain dan Industri Kreatif Universitas Esa Unggul.
}

\begin{abstract}
ABSTRAK
Toilet umum yang ideal tentunya harus dapat mudah dicapai dan nyaman saat digunakan. Saat ini di Jakarta telah tersedia mobil toilet umum keliling berbentuk bus yang dapat berpindah. Kawasan wisata Monas merupakan salah satu tempat yang memiliki mobil toilet keliling. Lingkungan kota Jakarta saat ini sudah mulai menyadari kehadiran para difabel (pengguna kursi roda), yaitu dengan membantu mengakomodir kebutuhan mereka. Contohnya dengan memasang ramp (akses tanjakan miring) yang menghubungkan jalan dengan halte transportasi publik, seperti di stasiun kereta api, bandar udara, halte busway, dan sebagainya. Metode yang digunakan dalam penelitian ini adalah metode penelitian kualitatif, dengan memilih strategi pengumpulan data fenomenologis yang melibatkan semua panca indera dalam melakukan pengamatan terhadap objek penelitian. Hal ini dimulai dari manusia sebagai pembuat dan pengguna artefak, unsur pembentuk wujud/objek, dan kandungan/muatan yang dimiliki artefak. Hasil penelitian akan dibandingkan, kemudian ditarik kesimpulan, dan akhirnya diberikan saran dan rekomendasi untuk masa depan toilet umum keliling, khususnya yang dapat digunakan untuk para difabel. Hasil penelitian toilet umum keliling ini akan memperlihatkan bahwa toilet umum dapat didesain khusus untuk para difabel dengan mempertimbangkan faktor ergonomi. Saran yang diberikan penulis pada akhir penelitian yaitu ingin agar desainer toilet dapat mulai turut dalam membantu para difabel, khususnya di kawasan wisata Monas.
\end{abstract}

Kata kunci: mobil toilet, difabel, penelitian kualitatif

\section{PENDAHULUAN}

Penyandang cacat dianggap mampu melakukan kegiatan sehari-hari layaknya orang normal. Mereka memang dapat kita samakan derajatnya dengan manusia lainnya, tetapi ada beberapa hal di mana mereka perlu diberikan akses bantuan untuk memudahkan aktifitas mereka. Pertama kali yang dibayangkan jika kita mendengar kata toilet umum, tak diragukan lagi hampir semua orang langsung memandang negatif. Suatu pemikiran terlintas pada benak kita akan suatu tempat di luar rumah yang kotor dan bau. Fenomena ini timbul karena para pengguna sendirilah yang biasanya mengabaikan kebersihan pemakaian toilet umum. Kesadaran dan budaya hidup bersih pada masyarakat masih rendah dalam memperhatikan lingkungan sekitar. Tingkat kenyamanan pengguna toilet tentunya akan terganggu jika toilet umum berada dalam keadaan kotor. Toilet umum yang berada di luar rumah hendaknya ditempatkan pada area-area yang mudah dijangkau. Pemerintah kota memiliki kebijakan tersendiri atas keberadaan dan kebersihan toilet umum tersebut. Tempat wisata merupakan lokasi di tiap kota yang merepresentasikan wajah kota secara keseluruhan. Lokasi ini didatangi oleh berbagai kelas masyarakat dan seharusnya dilengkapi dengan toilet bersih yang dapat ditemui dengan mudah. Fasilitas toilet ini digunakan bersama dengan orang lain, sehingga senantiasa harus berada dalam kondisi kering dan bersih agar pemakai toilet berikutnya dapat terjaga kesehatannya. Toilet umum selain yang dibangun permanen pada lokasi tertentu, terdapat pula toilet umum keliling. Toilet umum keliling ini sebaiknya ditempatkan di lokasi yang strategis agar masyarakat dengan mudah menjangkaunya dan dapat dipindahkan jika diinginkan. Saat ini di Indonesia, khususnya Jakarta telah memiliki beberapa buah mobil toilet keliling. Lokasi penempatannya diutamakan untuk kawasan wisata dan tempat-tempat bencana. Bentuk dari mobil toilet keliling saat ini semuanya hanya memiliki akses tangga untuk naik, sedangkan para difabel tentunya akan kesulitan dalam menggunakannya. Oleh karena itu, penelitian 
ini akan membahas desain interior mobil toilet keliling yang telah ada di kota Jakarta, dengan modifikasi akses bagi para difabel.

\section{RUMUSAN MASALAH}

Mobil toilet keliling saat ini hanya dapat digunakan oleh orang normal karena akses masuknya berupa tangga. Para difabel sebagai pengunjung kawasan wisata Monas, Jakarta Pusat apabila ingin ke toilet belum dapat terakomodasi kebutuhannya. Penulis merumuskan masalah tersebut menjadi bagaimana hasil desain mobil toilet keliling untuk difabel di kawasan Monas, Jakarta Pusat.

\section{TUJUAN PENELITIAN}

Penelitian ini bertujuan secara umum untuk mempelajari bagaimana fasilitas standar yang diperlukan para difabel dalam menggunakan toilet umum. Tujuan penelitian secara khusus adalah melihat bagaimana fasilitas yang dimiliki oleh mobil toilet keliling di kawasan Monas, Jakarta Pusat dapat didesain ulang demi kenyamanan para difabel. Hasil penelitian juga memberikan saran/rekomendasi atas desain mobil toilet keliling yang saat ini menurut peneliti masih terdapat kritik di beberapa aspek, sehingga penciptaannya di masa datang akan lebih baik lagi.

\section{TINJAUAN PUSTAKA}

Toilet umum adalah sebuah ruangan yang dirancang khusus lengkap dengan kloset, persediaan air dan perlengkapan lain yang bersih, aman, dan higienis di mana masyarakat di tempattempat domestik, komersial, maupun publik dapat membuang hajat serta memenuhi kebutuhan fisik, sosial, dan psikologis lainnya. Pengguna toilet umum adalah manusia normal atau penyandang cacat, baik pria maupun wanita, usia anak-anak sampai dewasa (Kementerian Kebudayaan dan Pariwisata, 2004: $4-5)$.

Menurut buku Standar Toilet Umum Indonesia "Kering itu Sehat" (2004: 6 - 13) kelengkapan dan besaran ruang untuk toilet, yaitu:

\section{Ruang untuk buang air besar (WC)}
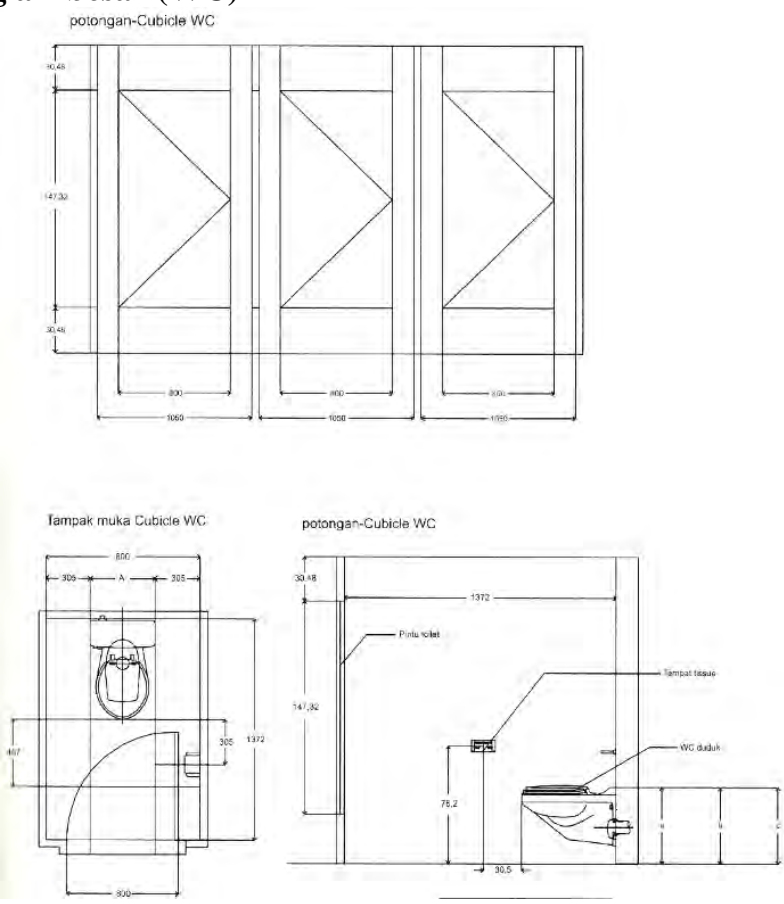

Gambar 1 Besaran ruang dengan kloset duduk 
(Sumber: Standar Toilet Umum Indonesia “Kering itu Sehat", 2004: 9)

Ruangan dilengkapi dengan kloset duduk/jongkok, air dan perlengkapannya (tempat air/gayung, keran, dan lain-lain). Penggunaan untuk orang normal, baik WC yang menggunakan kloset duduk maupun jongkok, sebaiknya memiliki ukuran luas minimum yang diukur dari poros/as $80 \mathrm{~cm} \times 150 \mathrm{~cm} \times 220 \mathrm{~cm}$. Sedangkan ukuran luas yang disarankan adalah $90 \mathrm{~cm} \times 160 \mathrm{~cm} \times 240$ $\mathrm{cm}$.

\section{Ruang untuk buang air kecil}
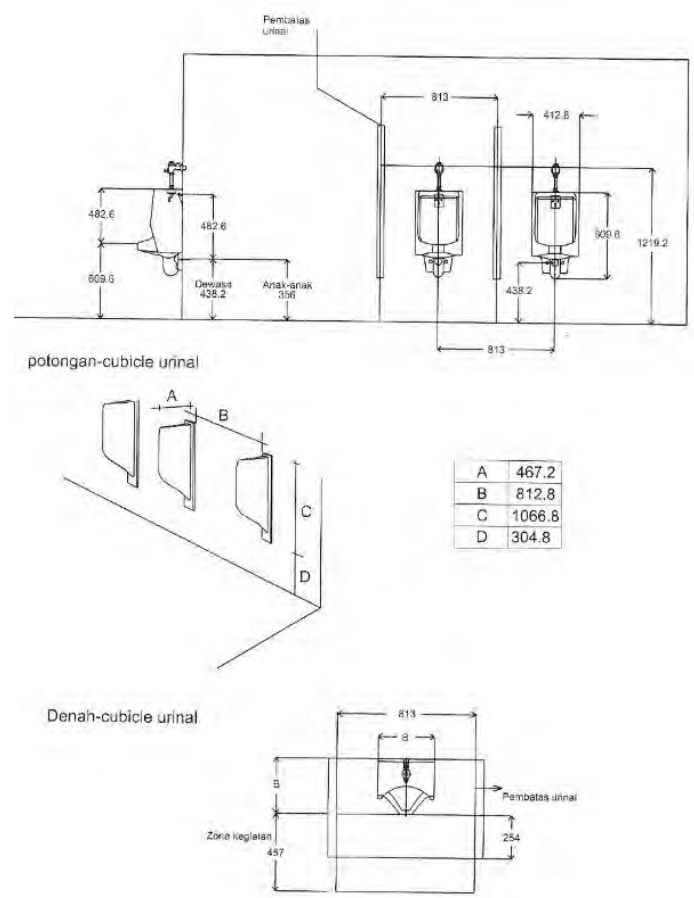

Gambar 2 Besaran ruang dengan urinal

(Sumber: Standar Toilet Umum Indonesia “Kering itu Sehat”, 2004: 11)

Ruangan dilengkapi dengan urinal, air dan perlengkapannya (tempat air/gayung, keran, dan lain-lain). Penggunaan untuk orang normal, lebar satuan minimum untuk aktifitas buang air kecil berdiri orang dewasa adalah $70 \mathrm{~cm}$ yang dilengkapi penyekat. Minimum ketinggian urinal yakni $40 \mathrm{~cm}$ dari lantai. Sedangkan untuk ukuran yang disarankan adalah lebar ruang $80 \mathrm{~cm}$, dengan ketinggian urinal minimum $45 \mathrm{~cm}$. Urinal bagi anak-anak dapat digunakan jenis floor standing.

\section{Ruang cuci tangan dan cuci muka (wastafel)}

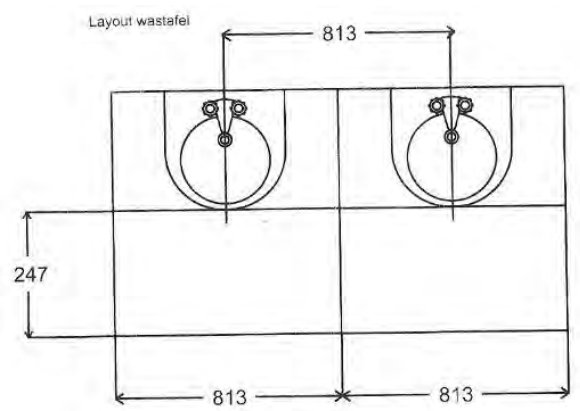

Gambar 3 Rencana Layout area wastafel

(Sumber : Standar Toilet Umum Indonesia “Kering itu Sehat”, 2004: 12) 


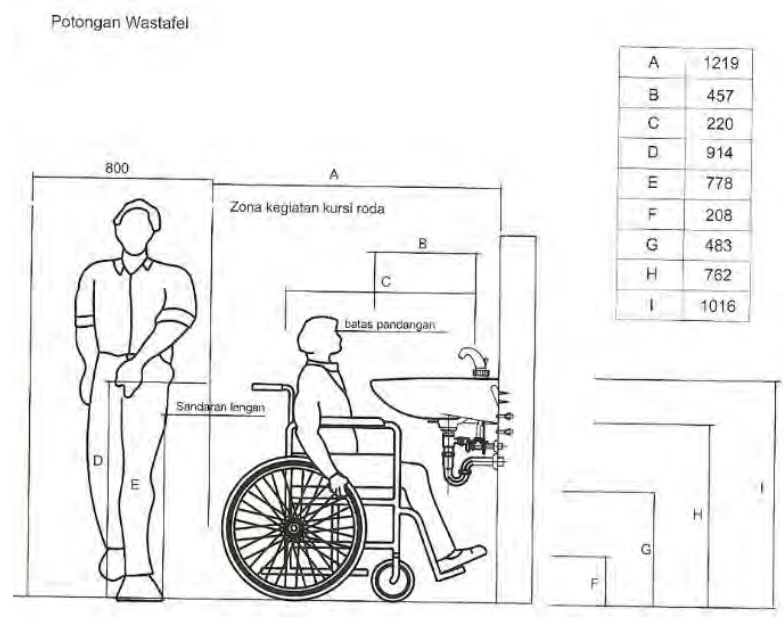

Gambar 4 Gambar Potongan area wastafel

(Sumber: Standar Toilet Umum Indonesia "Kering itu Sehat", 2004: 13)

Ruangan dilengkapi dengan wastafel, cermin, air dan perlengkapannya (tempat air, keran, dan lain-lain). Area minimum yang diperlukan pengguna normal untuk melakukan aktifitas cuci tangan dan cuci muka yaitu memiliki lebar $80 \mathrm{~cm}$, dengan lebar bak cuci $50 \mathrm{~cm}$, dan tinggi dari lantai $70 \mathrm{~cm}$. Rekomendasi ukuran adalah lebar area $90 \mathrm{~cm}$, lebar bak cuci $60 \mathrm{~cm}$, dan tinggi bak cuci dari lantai $80 \mathrm{~cm}$.

\section{Ruang penjaga dan pelayanan kebersihan (janitor),}

Ruangan dilengkapi dengan penggantung alat pembersih, lemari/rak simpan, bak pencuci, air dan perlengkapannya (tempat air, gayung, keran, dan lain-lain). Kebutuhan ruang untuk penjaga toilet umum memiliki luas sekitar $90 \mathrm{~cm}$ x $105 \mathrm{~cm}$.

Pada buku Standar Toilet Umum Indonesia “Kering itu Sehat" (2004: 14 - 22), hal yang berhubungan dengan bangunan toilet, antara lain:

\section{Bidang lantai, dinding, langit-langit}

Pada konstruksi bangunan, bidang lantai memiliki kemiringan $1 \%$ dari panjang atau lebar lantai. Bahan finishing/pelapis lantai bisa terbuat dari ubin keramik, semen plester/acian, atau batu alam yang tidak licin akan tetapi mudah dibersihkan dan kuat, untuk alternatif bisa digunakan lantai vinyl.

Dinding yang berwarna terang sangat memudahkan untuk kontrol kebersihan. Bahan dinding dapat menggunakan ubin keramik pada gypsum atau bata dengan lapisan tahan air. Bahan alternatif dinding dapat menggunakan dinding batako dengan cat tahan air. Pembatas/panel partisi yang digunakan sebagai penyekat antara WC satu dengan lainnya, disarankan menggunakan bahan panel yang ringan dan dilapisi dengan bahan yang tahan air. Pembatas/panel partisi biasanya dipasang $30 \mathrm{~cm}$ di atas lantai agar tidak mudah basah.

Pada bidang langit-langit terbuat dari bahan lembaran-lembaran yang cukup kaku dan rangka yang kuat, sehingga memudahkan perawatan dan tidak mudah kotor. Bahannya bisa menggunakan kayu lapis/triplek minimal $3 \mathrm{~mm}$, calciboard, anyaman bambu yang cukup rapat, dan sebagainya. Rangka langit-langit dapat menggunakan kayu, bambu, ataupun pipa besi (metal hollow). Apabila terdapat pipa di atas langit-langit, maka perlu dibuat lubang untuk orang masuk (man-hole) agar ada akses yang lebih mudah untuk perawatan dan perbaikan.

\section{Produk saniter toilet}

Produk kloset dan saniter lainnya harus dipastikan mempunyai bowl/leher angsa yang baik sebagai penahan bau. Masalah warna, sebaiknya semua saniter berwarna putih untuk memudahkan deteksi kotoran. Toilet umum juga sebaiknya melengkapi kloset dengan jet spray, 
washlet-eco (karena tidak semua orang menggunakan kertas toilet), dan menggunakan penyiraman sistem dual-flush (untuk menghemat penggunaan air bersih).

\section{Pintu dan jendela}

Pintu toilet umum harus terbuat dari bahan tahan air, ringan, dan mudah dibersihkan. Untuk penggunaan dengan frekuensi tinggi, seperti pada terminal bus atau pasar, akan lebih baik apabila mempunyai akses masuk dengan sirkulasi melingkar 'S' (akses lubang pintu tidak langsung mengarah pada ruang luar toilet sirkulasi/keramaian secara langsung, ada ruang antara, walau agak memutar) tanpa harus menggunakan daun pintu. Kusen pintu dan jendela ventilasi juga harus terbuat dari bahan yang tahan air dan mudah dibersihkan. Sebaiknya setiap pintu WC memiliki penutup pintu (door-closer) otomatis dan bisa dikunci dari dalam. Untuk penyandang cacat, pintu menggunakan jenis pintu geser atau sesuai dengan Keputusan Menteri Pekerjaan Umum KepMen 468/KPTS/1998 tentang persyaratan teknis aksesibilitas pada bangunan umum dan lingkungan. Pada daun pintu perlu disediakan pula gantungan untuk pakaian dan tas.

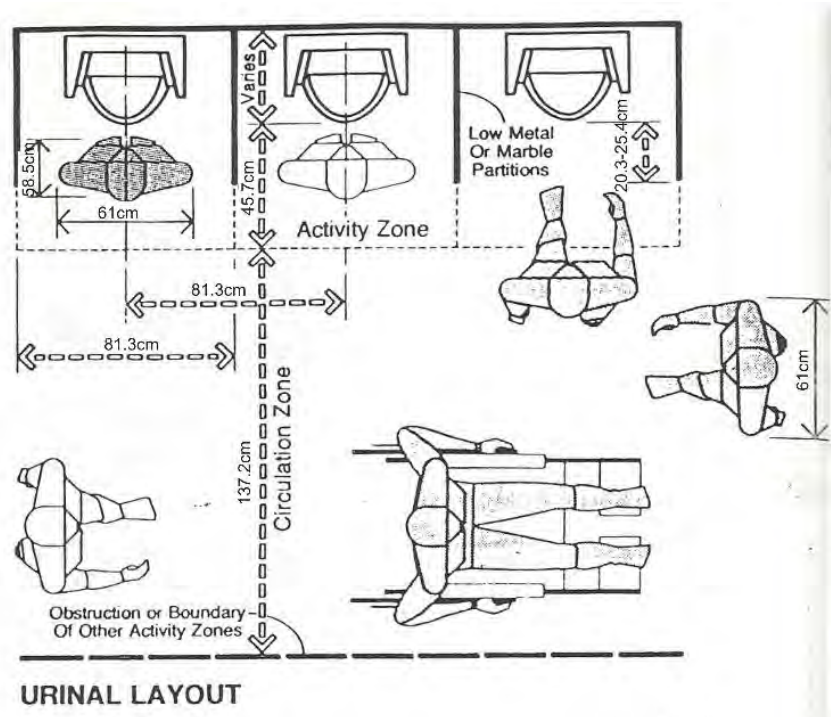

Gambar 5 Ergonomi \& antropometri tata letak urinal (Sumber: Julius Panero, 2006: 276)

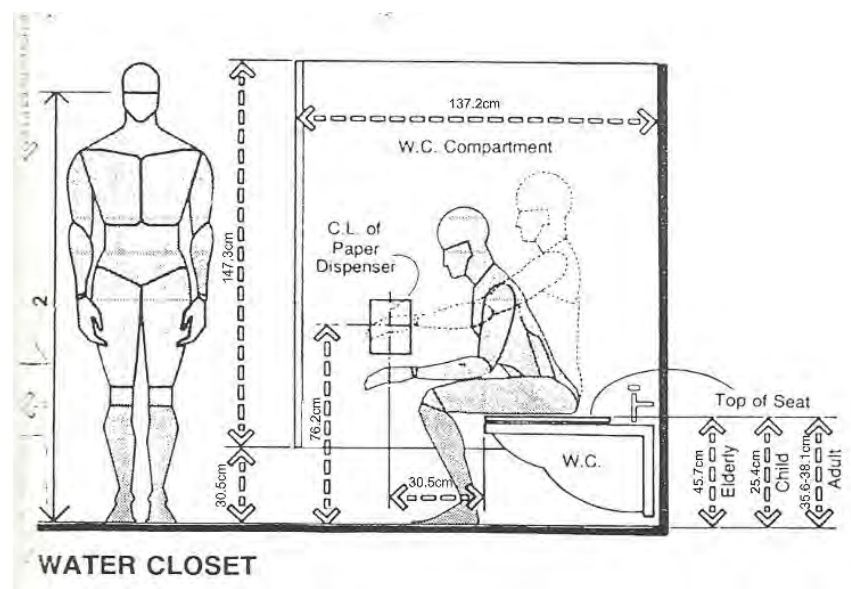

Gambar 6 Ergonomi \& antropometri penggunaan WC (Sumber: Julius Panero, 2006: 277) 
Sebagai acuan dalam mendesain toilet, terdapat beberapa ketentuan yang memuat standarisasi ukuran area toilet bagi pengguna kursi roda maupun orang normal. Area urinal umumnya tersedia dengan minimal pemasangan (as ke as) $53,3 \mathrm{~cm}$, tetapi hal ini tidak memuaskan bagi sebagian besar pengguna. Orang dengan postur tubuh besar memiliki lebar tubuh maksimal 66 $\mathrm{cm}$, maka ruang tentunya akan menjadi lebih lebar. Dengan antropometri kenyataan di lapangan dan pertimbangan akan ruang personal, $81,3 \mathrm{~cm}$ tentunya sudah dirasa cukup. Partisi sebaiknya memanjang sekitar 20,3-25,4 cm, dari jarak permukaan urinal, dan sebuah ruang aktifitas $45,7 \mathrm{~cm}$, di depan sarana seharusnya dipertimbangkan. Ruang sirkulasi $137,2 \mathrm{~cm}$, akan dapat mengakomodasi pejalan dan lalu-lintas kursi roda. Tinggi dari WC disarankan mempertimbangkan kebutuhan antropometri dari orang lanjut usia dan anak-anak (Julius Panero, 2006: 276 - 277).

Lingkungan untuk para difabel perlu dirancang mengakomodasi kursi roda dan alokasi ruang untuk berpindah ke sekeliling secara aman. Layout WC, misalnya, membutuhkan perencanaan yang hati-hati (Ernst Neufert, 2003: 298). Suatu area yang didesain secara baik dan efisien berfungsi adalah hal terpenting untuk orang dengan disabilitas. Untuk berputar $180^{\circ}$ satu pengguna kursi roda membutuhkan $1500-1700 \mathrm{~mm}$. Kebutuhan ini merupakan ukuran minimum pada area sirkulasi untuk mendarat. Akses masuk sebaiknya tidak memiliki rintangan atau anak tangga dan pintu berputar tidak diperkenankan. Pintu setidaknya memiliki lebar bersih $900 \mathrm{~mm}$. Pintu kamar mandi/WC harus dibuka keluar (Ernst Neufert, 2003: 301).

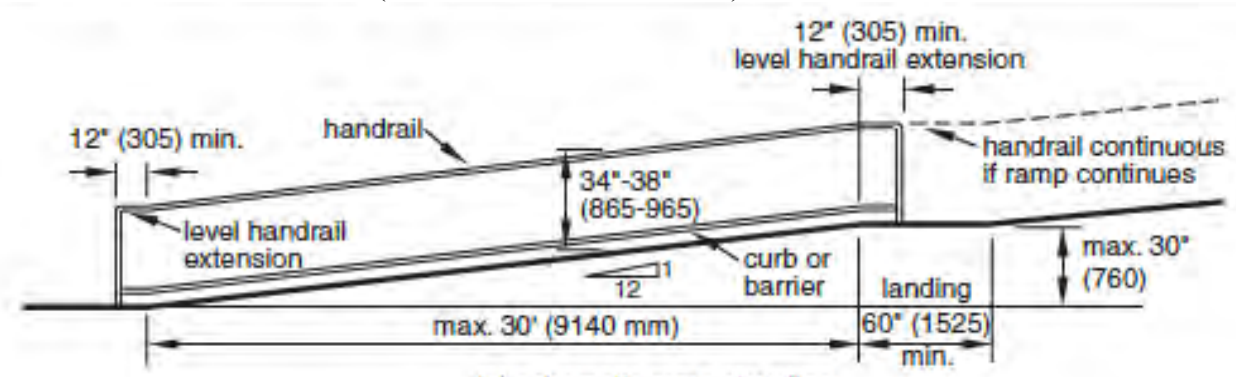

Gambar 7 Standar Dimensi Ramp

(Sumber: David Kent Ballast, 2010: 166)

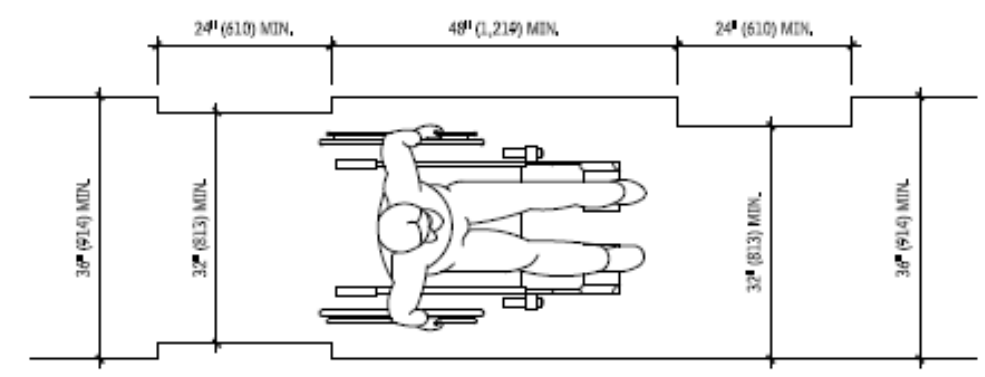

SINGLE VIHEELCHAIR

Gambar 8 Akses untuk pengguna kursi roda single (Sumber: Corky Binggeli, 2012: 22)

Ramp tidak dapat miring lebih dari ketinggian 1 unit setiap panjang 12 unit. Bagaimanapun, di mana-mana akses yang memungkinkan untuk ramp sebaiknya didesain dengan kemiringan kurang dari 1:12, hal ini ditujukan agar memudahkan pengguna memakainya dan juga sebagai batas toleransi konstruksi ketika ramp dibuat (David Kent Ballast, 2010: 166). Semua permukaan ramp harus kokoh, stabil, dan anti slip (Corky Binggeli, 2012: 22). Standar kebutuhan kemiringan ramp tidak lebih dari 1:12 (ketinggian berbanding panjang), dengan beberapa pengecualian untuk area terbatas pada tempat existing, bangunan, dan fasilitas (Corky Binggeli, 2012: 78). 


\section{METODE PENELITIAN}

Metode yang digunakan peneliti adalah metode penelitian kualitatif. Penelitian kualitatif secara umum dapat digunakan untuk penelitian tentang kehidupan masyarakat, sejarah, tingkah laku, fungsionaliasi organisasi, aktifitas sosial, dan lain-lain. Tujuan utama penelitian kualitatif adalah untuk memahami fenomena atau gejala sosial dengan cara memberikan pemaparan berupa penggambaran yang jelas tentang fenomena atau gejala sosial tersebut dalam bentuk rangkaian kata yang pada akhirnya akan menghasilkan suatu Hasil akhir dari penelitian kualitatif tidak menggunakan rancangan penelitian yang baku. Rancangan penelitian berkembang selama proses penelitian. Perspektif partisipan sangat diutamakan dan dihargai tinggi. Minat peneliti banyak tercurah pada bagaimana persepsi dan makna menurut sudut pandang partisipan yang diteliti, sehingga bisa menemukan apa yang disebut sebagai fakta fenomenologis (V.Wiratna Sujarweni, 2014: $19-20)$.

Pada penelitian ini peneliti menggunakan pendekatan fenomenologis yang melibatkan semua panca indera dalam melakukan pengamatan terhadap objek penelitian. Untuk itu peneliti akan memberikan paparan atas pengalaman yang dialami selama meneliti mobil toilet keliling di kawasan Monas, Jakarta Pusat. Penelitian ini memperoleh data teknik melalui survey lapangan terhadap mobil toilet keliling di kawasan Monas, Jakarta Pusat, pengumpulan data literatur mengenai kebersihan dan fasilitas toilet, pemantauan ergonomi dan antropometri pengguna kursi roda terhadap ruang interior, serta wawancara kepada para difabel (pengguna kursi roda) pada kawasan Monas, Jakarta Pusat. Waktu penelitian dilakukan antara bulan Maret 2018 sampai dengan November 2018.

\section{HASIL DAN PEMBAHASAN}

\section{Mobil Toilet Keliling di Monas}

Pada kawasan Monas terdapat fasilitas mobil toilet keliling tipe VIP yang disediakan oleh Pemerintah Daerah Jakarta Pusat ketika akhir pekan. Mobil toilet keliling yang dimaksud ini merupakan sebuah bus yang dimodifikasi menjadi toilet. Berbeda dengan toilet berbentuk kontainer yang harus menumpang kendaraan lain saat akan dipindahkan, mobil toilet jenis bus ini dapat berpindah langsung karena memiliki mesin layaknya kendaraan bus biasa.

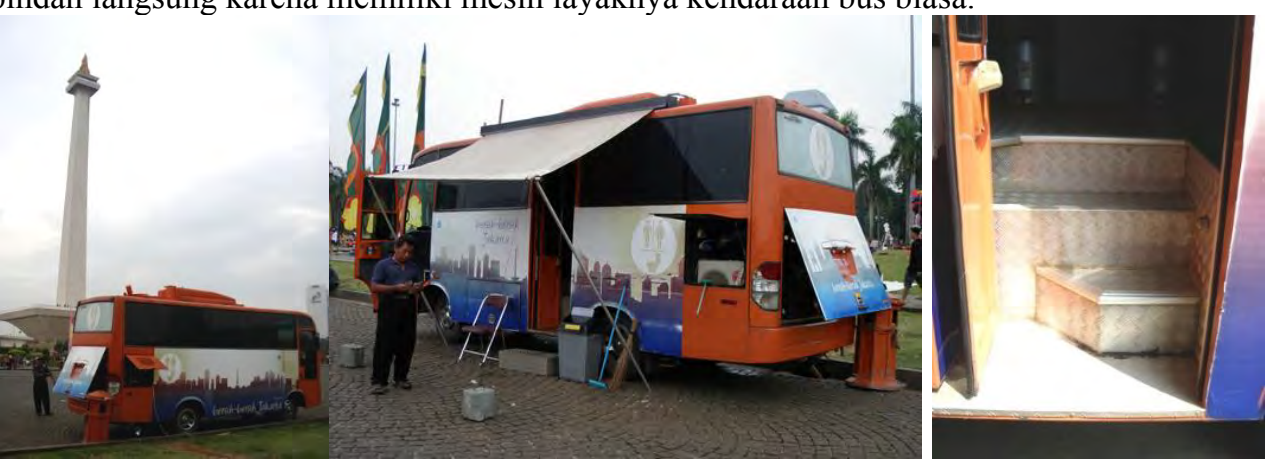

Gambar 9 Mobil toilet keliling di kawasan Monas, Jakarta Pusat; Gambar 10 Akses masuk mobil toilet keliling (Sumber: Dok. Irma Damayantie, 2018)

Mobil toilet keliling di kawasan Monas, Jakarta Pusat tidak dibedakan untuk pengguna pria dan wanita. Sama seperti toilet kontainer, mobil toilet dalam wujud bus ini tidak didesain khusus untuk kenyamanan pengguna difabel. Pijakan naik di dalam mobil toilet terdiri atas 3 anak tangga dengan ketinggian pijakan pertama pada mobil berada sekitar $40 \mathrm{~cm}$ dari tanah. 


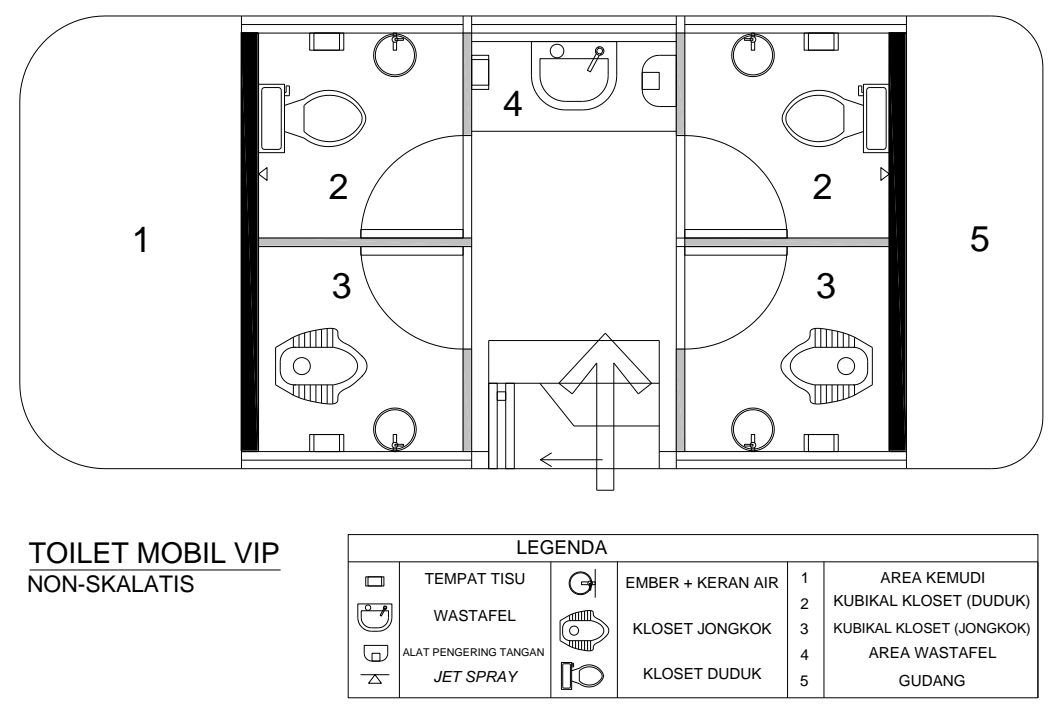

Gambar 11 Ilustrasi layout mobil toilet VIP

(Sumber: Dok. Irma Damayantie, 2018)

Pada gambar di atas peneliti membuat ilustrasi dari layout mobil toilet VIP yang disurvei pada kawasan Monas, Jakarta Pusat. Pembagian ruang mobil toilet keliling tersebut terdiri atas area kemudi (paling kiri dari gambar), area kubikal kloset (terletak di sisi kiri dan kanan pintu masuk ke dalam toilet), area wastafel (berada di muka pintu masuk), dan area penyimpanan/gudang (pada bagian belakang bus).

\section{Pengunjung Difabel di Kawasan Monas dan Permasalahannya}

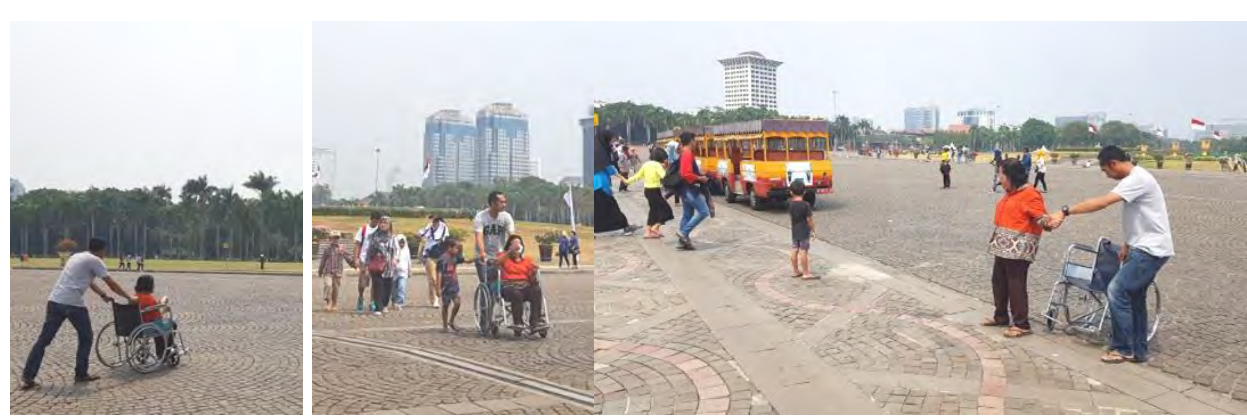

Gambar 12 Pengunjung difabel di kawasan Monas

(Sumber: Dok. Irma Damayantie, 2018)

Berdasarkan pemantauan peneliti, terlihat bahwa pengguna kursi roda mengalami kesulitan saat berkeliling di kawasan Monas, Jakarta Pusat. Sekeliling tugu Monas menggunakan bahan lantai bata blok yang dibuat berpola. Pengguna kursi roda terpaksa harus menahan ketidak nyamanan mereka saat melintas, karena setiap nat pemisah bata blok yang terlewati akan membuat guncangan pada kursi roda. Pada gambar di atas terlihat bahwa tidak tersedia ramp yang memudahkan akses pengguna kursi roda untuk berpindah ke tempat yang lebih tinggi. 

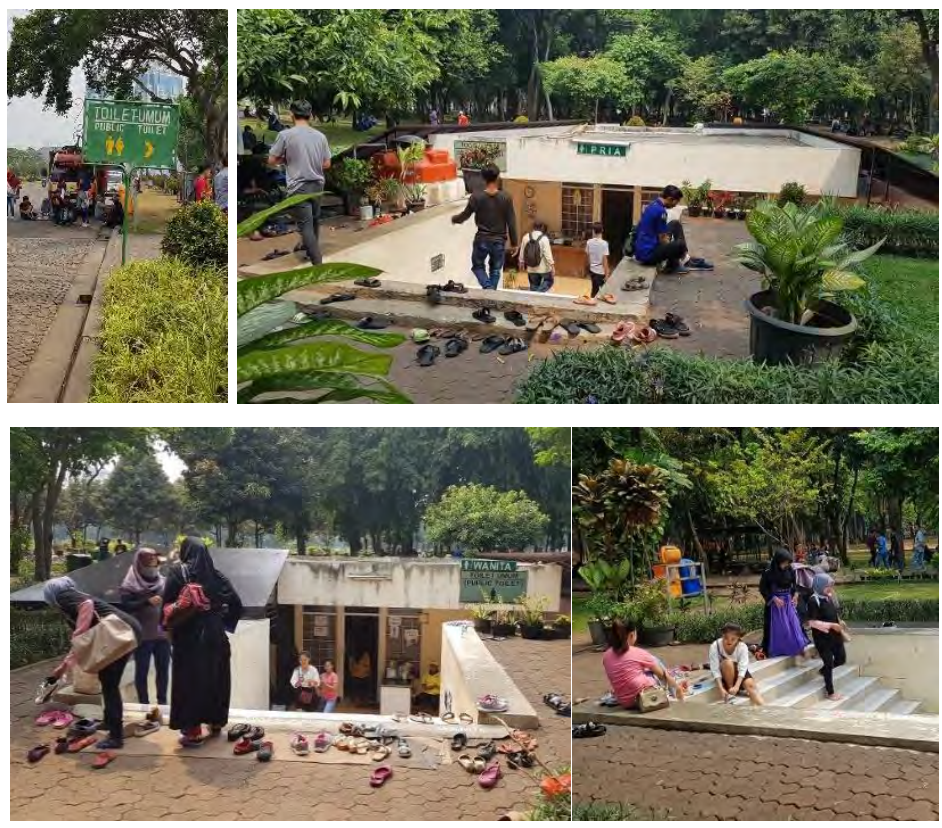

Gambar 13 Akses jalan menuju ke toilet umum di kawasan Monas (Sumber: Dok. Irma Damayantie, 2018)

Kawasan Monas, Jakarta Pusat memiliki toilet umum permanen, namun pada Gambar 13 terlihat bahwa akses jalan menuju ke toilet umum tidak dilengkapi dengan ramp. Toilet umum permanen tersebut berlokasi di bawah, sehingga pengunjung harus melewati deretan anak tangga. Pengguna toilet juga diwajibkan untuk melepas alas kaki sebelum masuk. Nampaknya pengguna kursi roda belum mendapatkan perhatian khusus dari pengelola kawasan Monas, Jakarta Pusat.

\section{Fasilitas Mobil Toilet Keliling untuk Difabel}

Setelah menganalisis data dari mobil toilet keliling yang sudah ada dan melakukan obeservasi lapangan serta mempelajari ergonomi dan antropometri dari pengguna kursi roda, maka pada bagian ini peneliti akan mengemukakan usulan baru atas desain mobil toilet keliling yang mempertimbangkan penggunaan bagi difabel.
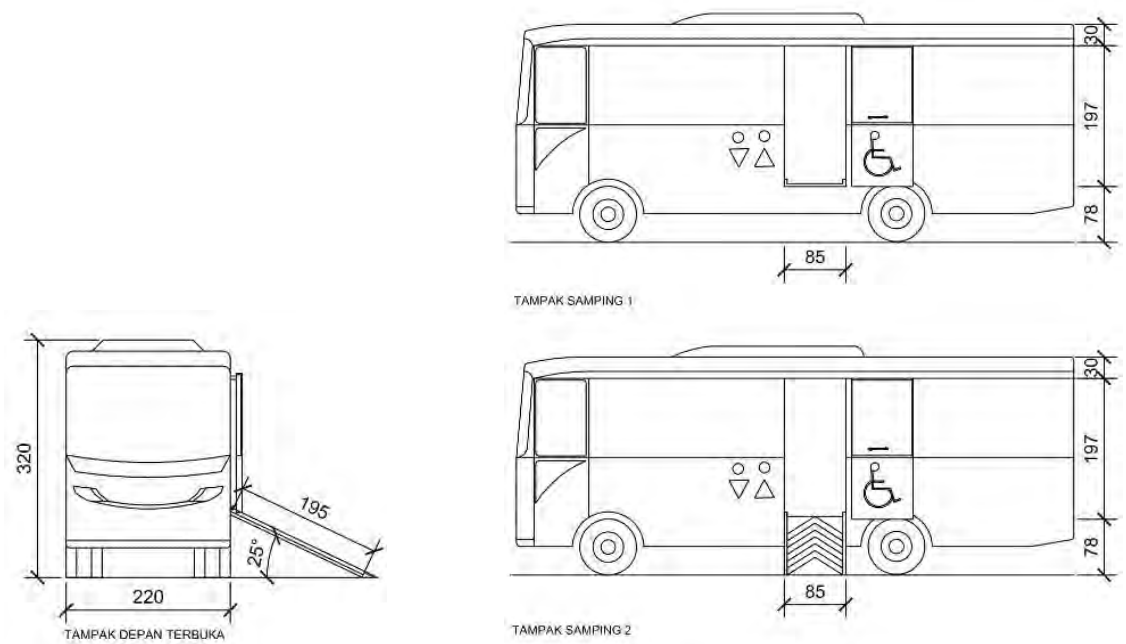

Gambar 14 Tampak depan dan tampak samping usulan desain mobil toilet keliling untuk difabel (Sumber: Dok. Irma Damayantie, 2018) 
Pada Gambar 14 peneliti menampilkan tampak depan dan samping dari usulan desain mobil toilet keliling. Bentuk mobil toilet yang saat ini ada tidak peneliti ubah, sehingga masih menggunakan ukuran existing. Pada pemodelan ulang ini peneliti menambahkan ramp yang disisipkan pada bagian bawah pintu masuk. Ramp diperhitungkan cukup untuk diletakkan selebar badan mobil toilet keliling. Ukuran kemiringan ramp dibuat $25^{\circ}$ dengan mempertimbangkan aspek ergonomi. Akses pintu masuk yang sebelumnya dibuka dalam keadaan terlipat, oleh peneliti diubah menjadi pintu geser. Pergeseran pintu dibuat ke arah luar. Hal ini dimaksudkan agar tidak ada ruangan yang terpakai untuk melipat pintu pada sisi interior. Pada badan mobil toilet keliling diberikan simbol pengguna wanita dan pria, serta penambahan simbol pengguna difabel. Simbol ini mengartikan bahwa penggunaan toilet bersifat unisex (tidak dikhususkan untuk salah satu jenis kelamin saja).

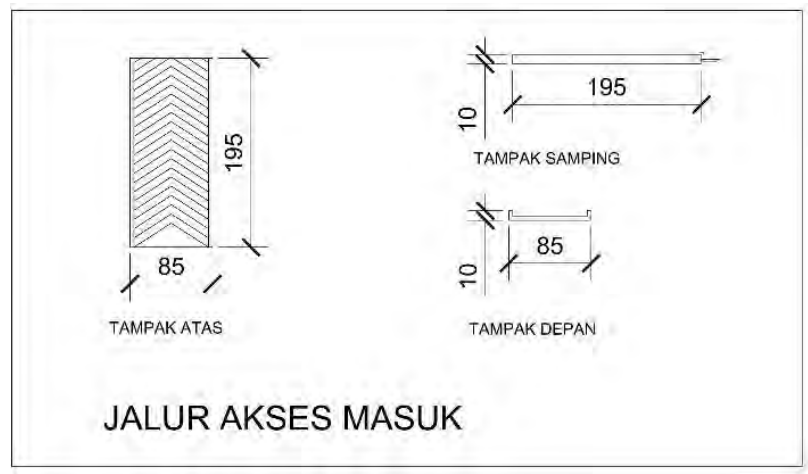

Gambar 15 Detail ramp pada usulan desain mobil toilet keliling untuk difabel (Sumber: Dok. Irma Damayantie, 2018)

Peneliti mengganti tangga sebagai akses masuk pengguna ke dalam toilet menjadi lereng (ramp), sehingga dapat mempermudah akses pengguna kursi roda untuk naik. Pada Gambar 15 tersaji gambar proyeksi orthogonal dari jalur akses masuk selebar $85 \mathrm{~cm}$ dan panjang $195 \mathrm{~cm}$. Ramp dibuatkan edging pada sisi kiri dan kanan setinggi $10 \mathrm{~cm}$ agar pengguna kursi roda dapat aman saat naik dan tidak meluncur turun dari sisi kiri atau kanan. Ramp diusulkan untuk dibuat dari bahan alumunium dengan dasar bertekstur agar tidak licin saat pengguna akan naik ke atas. Bahan ramp dipilih yang kuat dan tahan untuk mobilisasi pengguna kursi roda.

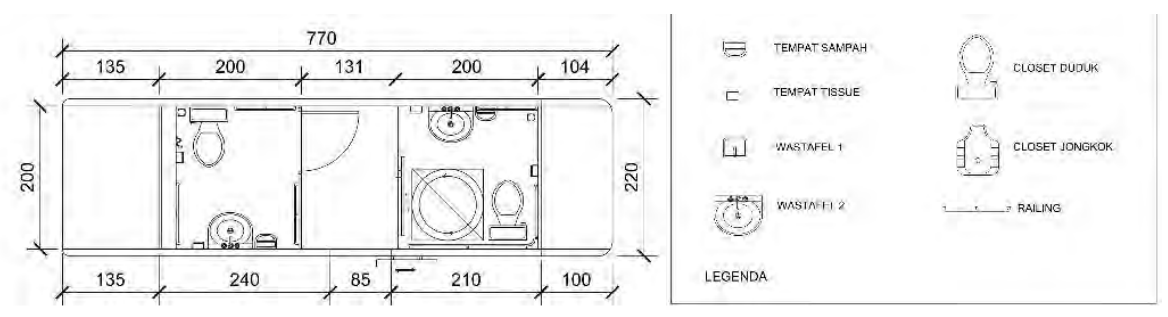

Gambar 16 Layout usulan desain mobil toilet keliling untuk difabel (Sumber: Dok. Irma Damayantie, 2018)

Fasilitas yang tersedia pada mobil toilet keliling untuk difabel tidak jauh berbeda dengan mobil toilet keliling yang saat ini ada. Pada usulan desain yang menurut peneliti adalah yang terbaik, fasilitas toilet terdiri atas: kloset duduk, wastafel, tempat sampah dan tempat tissue, serta penambahan hand rail sebagai alat bantu pegangan bagi pengguna difabel saat menggunakan kloset. Mobil toilet VIP yang sebelumnya terdapat 4 kubikal kloset di dalamnya, pada usulan desain baru berkurang menjadi hanya 2 kubikal kloset saja. Kubikal kloset yang diusulkan terdiri atas: 1 kubikal dengan bukaan pintu ke luar dan 1 kubikal dengan bukaan pintu geser. Peneliti membuat desain ini untuk pengguna difabel, tetapi tidak menutup kemungkinan bahwa mobil toilet keliling ini digunakan oleh orang normal. Hal yang menjadi perhatian peneliti adalah bahwa pengguna toilet difabel bukanlah orang asing yang perlu diisolasi, mereka adalah bagian dari masyarakat. Kubikal 
toilet dengan pintu geser dilengkapi dengan akses rotasi di lantai karena ruang gerak yang terbatas. Bahan lantai, dinding, dan langit-langit tidak mengalami perubahan dari kondisi existing.
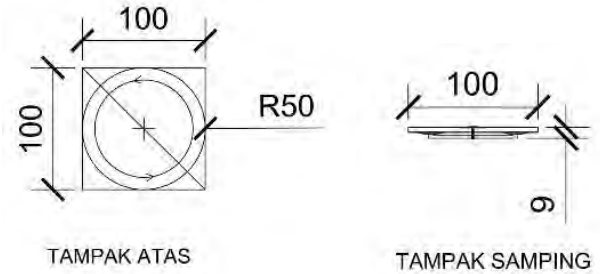

Gambar 17 Detail rotasi pada interior mobil toilet keliling untuk difabel

(Sumber: Dok. Irma Damayantie, 2018)
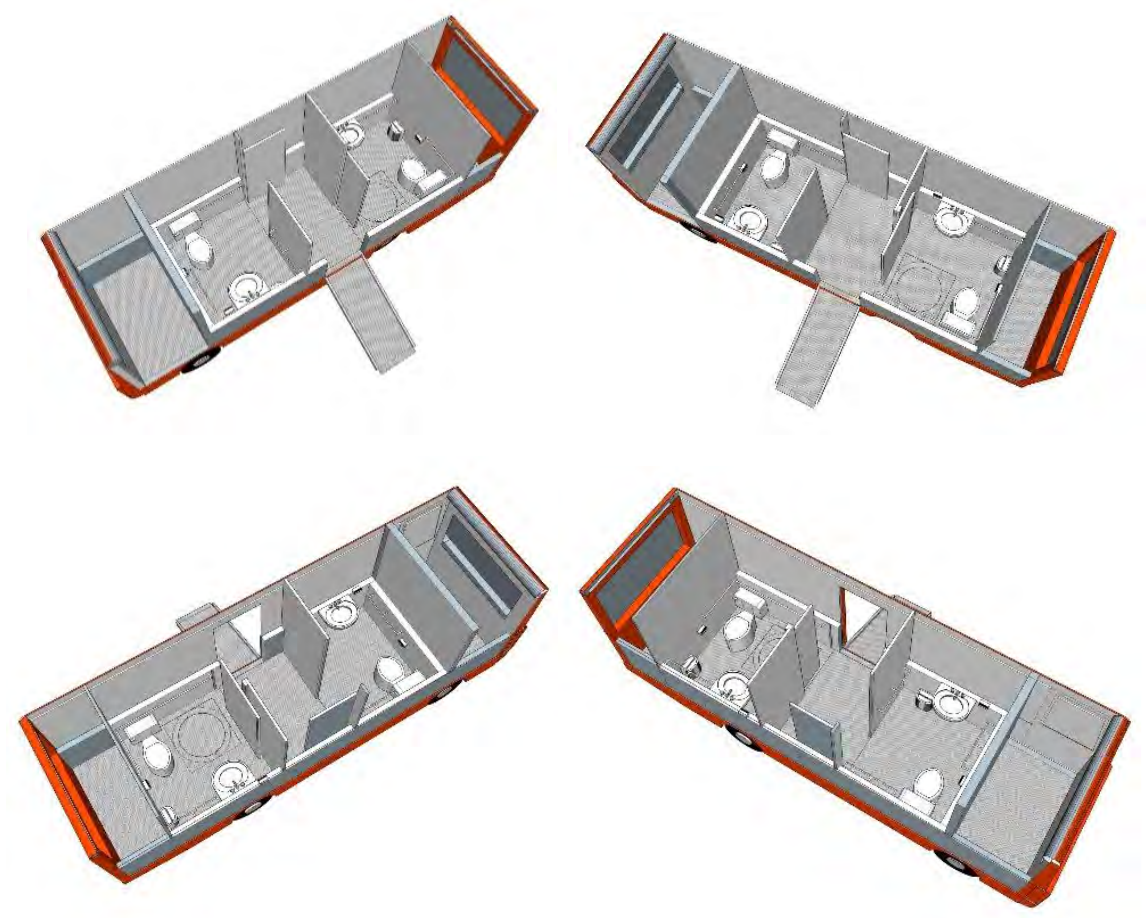

Gambar 18 Ilustrasi 3D atas usulan desain mobil toilet keliling untuk difabel

(Sumber: Dok. Irma Damayantie, 2018)

Fasilitas pendukung yang sudah ada pada kondisi existing mobil toilet saat ini tidak dihilangkan oleh peneliti. Mengenai akses rotasi untuk difabel dapat dilihat gambar kerjanya pada Gambar 17. Rotasi ini dimaksudkan agar pengguna kursi roda dapat memutar kursi mereka ke arah yang diinginkan pada area yang terbatas. Akses rotasi ini memiliki panjang dan lebar $100 \mathrm{~cm} \times 100$ $\mathrm{cm}$. Pengguna kursi roda dapat bermanuver setengah lingkaran atau $180^{\circ}$. Walaupun pada gambar proyeksi terlihat ketinggian akses tersebut adalah $9 \mathrm{~cm}$, tetapi saat pemasangan akan memiliki ketinggian sama seperti lantai toilet. Tampak interior 3 dimensi dari 4 sudut pandang atas usulan desain mobil toilet keliling untuk difabel dapat dilihat pada Gambar 18 di atas.

\section{KESIMPULAN DAN SARAN}

Berdasarkan hasil analisis data dan hasil penelitian yang telah dikemukan sebelumnya, maka peneliti mengambil kesimpulan bahwa mobil toilet keliling di kawasan Monas, Jakarta Pusat saat ini hanya menyediakan toilet untuk penggunaan bagi orang normal. Mobil toilet keliling yang menjadi fasilitas kawasan Monas merupakan toilet premium bertipe VIP. Mobil toilet keliling untuk difabel yang telah diusulkan bentuk desain interiornya oleh peneliti, semua kubikalnya dapat digunakan baik untuk pengguna difabel maupun orang normal. Hal ini dimaksudkan agar pengguna 
difabel tidak dibedakan atau merasa diasingkan dengan pengguna toilet pada umumnya, sehingga penggunaan mobil toilet keliling ini adalah bersifat universal.

Saran dari peneliti antara lain agar di masa datang Dinas Kebersihan dapat mempertimbangkan pengadaan mobil toilet keliling yang sesuai dengan ergonomi dan antropometri untuk pengguna difabel lainnya. Mobil toilet keliling jenis VIP agar dapat diperbanyak jumlahnya, sehingga kawasan wisata lain dapat menikmati fasilitas ini. Mobil toilet keliling diharapkan dapat menerapkan efisiensi energi, sehingga kelestarian lingkungan dapat terus terjaga.

\section{DAFTAR PUSTAKA}

Anthony, K. H. \& Meghan Dufresne. (2009). Potty Privileging in Perspective: Gender and Family Issues in Toilet Design (Ladies and Gents: Public Toilets and Gender). Philadelphia: Temple University Press.

Asosiasi Toilet Indonesia. (2007). Toilet Umum Indonesia. Jakarta.

Ballast, David Kent, FAIA, CSI. (2010). Interior Detailing: Concept to Construction. New Jersey: John Wiley $\&$ Sons, Inc.

Binggeli, Corky, ASID. (2012). Interior Graphic Standards. $2^{\text {nd }}$ Edition. New Jersey: John Wiley \& Sons, Inc.

Hudson, Jennifer. (2008). Restroom: Contemporary Design. London: Laurence King Publishing Ltd.

Kementerian Kebudayaan dan Pariwisata. (2004). Membangun Toilet Umum dengan Mudah "Kering itu Sehat". Jakarta.

Neufert, Ernst, Peter Neufert. (2003). Architects's Data. $3^{\text {rd }}$ Edition. New Jersey: John Wiley \& Sons, Inc.

Panero, Julius, AIA., ASID \& Martin Zelnik, AIA., ASID. (2006). Dimensi Manusia \& Ruang Interior. Jakarta: Erlangga.

Schuster, Cristina del Valle. (2005). Public Toilet Design: From Hotels, Bars, Restaurants, Civic Buildings and Businesses Worldwide. Savigliano: Firefly Books.

Sujarweni, V. Wiratna. (2014). Metodologi Penelitian. Yogyakarta : PUSTAKA BARU PRESS.

Zastrow, Charles \& Karen K. Krist-Ashman. (2010). Understanding Human Behavior and the Social Environment. Belmont : Brooks/Cole. 